\title{
Evaluation of anthropogenic sustainability of agro-gray forest soil in intensive agriculture by change of its biological activity indicators
}

\author{
Sufia Murtazina, Lilia Gaffarova*, Malik Murtazin, and Alfia Saimardanova \\ Kazan State Agrarian University, 420015 Kazan, Russia
}

\begin{abstract}
Studies have been carried out with the identification of criteria for the anthropogenic stability of agro-gray forest soils according to the main indicators of biological activity under conditions of intensive farming. Soils of this type are dominant in the soil cover of the Republic of Tatarstan, so the results of the experiment can be widely interpolated to similar conditions of soil formation and serve as quickly defined markers for diagnosing anthropogenic pressure. Studies have been carried out in field crop rotation since 1992, using various doses of potassium at three levels of soil nitrogen supply. As a result of long-term use of fertilizers, changes in microbiological activity have been revealed, in the variant with the use of environmentally balanced doses of mineral nutrition, an increase in microorganisms from 3,400 thousand (control) to 4,000 thousand per $1 \mathrm{~g}$ of soil is observed. A subsequent increase in the dose of fertilizers led to a decrease in the number of microorganisms relative to the control. Under the influence of the optimal combination of fertilizers (option 3), conditions for the development of actinomycetes, ammonifiers, nitrifiers, cellulose-decomposing bacteria are improved, while very high doses of mineral fertilizers $\left(\mathrm{N}_{180} \mathrm{P}_{60} \mathrm{~K}_{200}\right)$ worsen them, indicating a decrease in the activity of beneficial bacterial microflora. This leads to a slowdown in decomposition of fiber, nitrification and other biochemical processes. Indicators of the biological activity of the soil correlate among themselves, as well as with other indicators of its fertility, with the productivity of crop rotation and therefore can serve as an additional diagnostic sign when assessing the anthropogenic stability of the agricultural soil of the agricultural soil in intensive agriculture.
\end{abstract}

\section{Introduction}

The problem of soil and ecosystem resistance to various types of anthropogenic impacts is one of the fundamental problems of modern natural science, including soil science. Especially relevant is the assessment of the anthropogenic stability of agrogenic soils under conditions of intensive farming. In modern agriculture, the agro-gray soils of the Republic of Tatarstan are subjected to strong anthropogenic pressure, because the share of arable land in the structure of agricultural land reaches $75-80$ percent or more, and mineral fertilizers and agrochemicals are used intensively $[1,2]$.

According to a number of researchers, the intensive processing and use of agrochemicals, including mineral fertilizers, contributes to destabilization of the humus state of soils and reduce their environmental sustainability [3-6].

The statistical evaluation of the results of a continuous agrochemical survey of the soils of the republic and detailed studies of the humus state of agrogray forest soils in a long-term experiment with fertilizers confirm these conclusions [7].

Since soil organic matter is a source of energy for soil organisms and provides plants with the main nutrients, the energy potential of soil organic matter determines its fertility and environmental sustainability [8].

To assess the anthropogenic soil resistance, various indicators of soil condition are used, which are associated with different types of resistance. When they are selected, the sensitivity of the indicator is important, that is, its noticeable variability under the influence of the anthropogenic factor and informativeness, which is expressed in the presence of a close correlation between the studied indicator, anthropogenic factor and other soil properties.

The assessment of anthropogenic stability of forest soil agro-grasses in intensive farming by changing the indicators of its biological activity with long-term intensive use of mineral fertilizers has been conducted for the first time in the stationary field experiment in Antilles, the Republic of Tatarstan.

The number, composition of soil microflora and its activity are determined by soil genesis, ecological conditions; they primarily depend on their energy potential and hydrothermal regime, and at the same time the use of fertilizers, including mineral fertilizers, in agrogenic soils [9].

\footnotetext{
*Corresponding author: gaffarovalylya @mail.ru
} 
Under favorable conditions, the number of microorganisms and their activity after soil fertilization increases significantly, and the increased activity of microflora in fertilized soils leads to biological fixation of up to 30-40\% of mineral elements introduced [10].

Summarizing the above, we note that the consistently high biological activity of the soil is one of the main conditions ensuring the environmentally sustainable state of the agroecosystem.

\section{Materials and research methods}

In order to study changes in soil biodynamics under the influence of long-term use of fertilizers in crop rotation, research was carried out on the stationary experiment of the Department of Agrochemistry and Soil Science at Kazan State Agrarian University, which was founded in 1992 with grain crops in field crop rotation.

The field experiment included the study of the effectiveness of various doses of potassium (40,80, 120, $160,200 \mathrm{~kg} / \mathrm{ha})$ at three levels of soil nitrogen supply $(60,120,180 \mathrm{~kg} / \mathrm{ha})$. The alternation of crops in crop rotation: 1. Spring wheat; 2. Barley; 3. Oats; 4. Clean fallow; 5 . Winter rye.

The soil of the experimental site is agro-gray medium loamy, before laying the experiment it was characterized by the following agrochemical indicators: humus content - 2.8-3.5\%, the sum of exchange bases 19-25 mg/eq, hydrolytic acidity - 3-4 mg/eq, degree of saturation with bases $77-85 \%, \mathrm{pH}$ of sol. 5.5-6.0. The content of mobile forms of phosphorus and potassium were respectively $100-120$ and $110-130 \mathrm{mg}$ per $\mathrm{kg}$ of soil, i.e. It is a medium source of nutrition.

In order to assess the anthropogenic soil stability in intensive agriculture, after completing the 4th rotation of the crop rotation (after 20 years), we studied the biological state of of agro-gray soil in some variants: control (without fertilizers) and experiment options with varying degrees of fertilizer saturation. Experiment scheme: 1. Control - without fertilizers. 2. $\mathrm{N}_{60} \mathrm{P}_{60} \mathrm{~K}_{40}$ 3. $\mathrm{N}_{120} \mathrm{P}_{60} \mathrm{~K}_{120}$ 4. $\mathrm{N}_{180} \mathrm{P}_{60} \mathrm{~K}_{200}$.

The annual dose of phosphorus on the background of nitrogen and potash fertilizers was $50-70 \mathrm{~kg} / \mathrm{ha}$. Over the years of research, in the variants with a moderate dose of nitrogen $\left(\mathrm{N}_{60}\right)$, about $1000 \mathrm{~kg} / \mathrm{ha}$ of nitrogen were introduced, against the background of $\mathrm{N}_{120}$, respectively, $2000 \mathrm{~kg} / \mathrm{ha}$ of nitrogen, and against the background of $\mathrm{N}_{180}$, just $3000 \mathrm{~kg} / \mathrm{ha}$ of nitrogen were deposited.

At the same time, about $900 \mathrm{~kg} / \mathrm{ha}$ of phosphorus, from 700 to $3000 \mathrm{~kg} / \mathrm{ha}$ of $\mathrm{K}_{2} \mathrm{O}$ were deposited on all nitrogen backgrounds, depending on the type of experiment. Thus, NPK from 2,600 to 7,000 kg/ha as has been added to the soil of experimental variants over the years of research.

\section{Research results}

Studies have shown that under the influence of long-term use of mineral fertilizers, the agrochemical properties of the soil change, in particular, its acidity increases (see table). Microbiological analysis revealed that, in general, the soils of the experimental plots have reduced microbiological activity.

The total number of microorganisms is minimal in the soil of the control variant and the long-term use of fertilizers in environmentally balanced doses increased their numbers from 3,400 thousand in the control to 4,000 thousand per $1 \mathrm{~g}$ of soil in the soil of variant $\mathrm{N}_{120} \mathrm{P}_{60} \mathrm{~K}_{120}$. However, a further increase in the dose of fertilizers $\left(\mathrm{N}_{180} \mathrm{P}_{60} \mathrm{~K}_{200}\right)$ negatively affected the number of microorganisms and in the soil of this option, they became less prominent relative to the control (see table 1).

Table 1. The effect of long-term use of mineral fertilizers on the microbiological state of gray forest soil (in thousands per $1 \mathrm{~g}$ of soil)

\begin{tabular}{|c|c|c|c|c|c|}
\hline * & p H s o 1 & 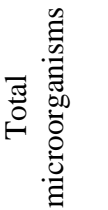 & $\begin{array}{l}\mathscr{E} \\
\stackrel{0}{0} \\
\Xi \\
\Xi\end{array}$ & 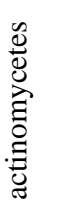 & 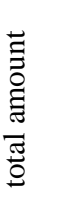 \\
\hline 1 & 5.6 & 3400 & 300 & 1000 & 2100 \\
\hline 2 & 5.4 & 3900 & 600 & 1200 & 2100 \\
\hline 3 & 5.2 & 4000 & 1000 & 1200 & 1800 \\
\hline 4 & 5.0 & 3300 & 1800 & - & 1700 \\
\hline
\end{tabular}

*Note. 1. Control - without fertilizers. 2. $\mathrm{N}_{60} \mathrm{P}_{60} \mathrm{~K}_{40}$

3. $\mathrm{N}_{120} \mathrm{P}_{60} \mathrm{~K}_{120} \quad$ 4. $\mathrm{N}_{180} \mathrm{P}_{60} \mathrm{~K}_{200}$

Table 1. continuation

\begin{tabular}{|c|c|c|c|c|c|c|}
\hline \multirow[b]{2}{*}{ 苛 } & \multicolumn{6}{|c|}{ Bacterium } \\
\hline & 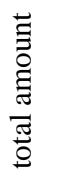 & 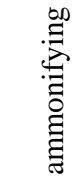 & . & 离 & 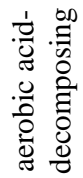 & 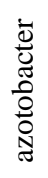 \\
\hline 1 & 2100 & 2005 & 70 & 0.02 & 20 & 1 \\
\hline 2 & 2100 & 1974 & 100 & 0.02 & 24 & 2 \\
\hline 3 & 1800 & 1654 & 115 & 0.25 & 30 & 1 \\
\hline 4 & 1700 & 1614 & 50 & 0.35 & 35 & 1 \\
\hline
\end{tabular}

With regard to the composition and quantity of microorganisms, these indicators are subject to varying dependence on the intensity of fertilizer use. The total number of bacteria is inversely related to the amount of fertilizer applied, i.e. with increasing doses of nitrogen and potassium, their number decreases.

The amount of ammonifying microorganisms changes in the same way. So, the ammonifying microorganisms are present in the soil of the control variant - without fertilizers, and in the variants with fertilizers their quantity gradually decreases with increasing doses of fertilizers.

Nitrifying microorganisms have their soil maxima in variants 2 and 3, i.e. at optimum saturation with nitrogen (doses of 60 and $120 \mathrm{~kg} / \mathrm{ha}$ ) and their minimum amount was found in the soil of option 4 , i.e. with prolonged use of very high doses of nitrogen $(180 \mathrm{~kg} / \mathrm{ha})$.

In the soil without fertilizers, azotobacter has a weak growth, the diameter of the colonies is less than $0.1 \mathrm{~cm}$, other nitrogen fixers have not been identified. The 
annual use of fertilizers in doses of $\mathrm{N}_{60} \mathrm{P}_{60} \mathrm{~K}_{40}$ and $\mathrm{N}_{120} \mathrm{P}_{60} \mathrm{~K}_{120}$ optimizes the microbiological state of the soil, therefore in the soils of these experiment options the nitrogen fixers are more lively, the azotobacter colonies are more enlarged and the nitrogen fixers are represented by a little less than one cell per $1 \mathrm{~g}$ of soil.

A very high dose of nitrogen (variant $\mathrm{N}_{180} \mathrm{P}_{60} \mathrm{~K}_{200}$ ) stimulates the development of denitrifiers and in the soil of this variant their number increases dramatically, which can lead to the removal of mineral forms of nitrogen from the soil.

Mold fungi are the smallest in the soil of the control variant and the variant with a moderate dose of fertilizers $\left(\mathrm{N}_{60} \mathrm{P}_{60} \mathrm{~K}_{40}\right)$, and as the doses of fertilizers increase, their number sharply increases, which is apparently due to acidification of the soil.

The number of actinomycetes in the soil without fertilizers is minimal, 2 to 3 times higher in the soil of the variants $\mathrm{N}_{60} \mathrm{P}_{60} \mathrm{~K}_{40}$ and $\mathrm{N}_{120} \mathrm{P}_{60} \mathrm{~K}_{120}$ and not at all detected in the variant with very high doses of fertilizers (var. $\mathrm{N}_{180} \mathrm{P}_{60} \mathrm{~K}_{200}$ ).

The change in the group composition of microorganisms indicates that the number of microorganisms that create potential fertility exceeds the number that create effective fertility and nitrogen fertilizer more stimulates the vital functions of the former and, with an optimal combination of nutrients, positively affects the latter.

Mineral fertilizers are a powerful anthropogenic factor that regulate the intensity of biochemical processes and their orientation. Therefore, differences in the microbiological composition under the action of fertilizers are reflected in other indicators of the biological activity of the soil.

Under the action of long-term use of fertilizers, the intensity of nitrification, cellulose decomposition and other biochemical reactions is reduced. So, if the nitrifying ability of the soil of the control variant is $1.8 \mathrm{mg}$ per $100 \mathrm{~g}$ of soil, in the variants with nitrogen fertilizers in doses of 60 and $120 \mathrm{~kg} / \mathrm{ha}$ it increases $1.5-3$ times.

The intensity of decomposition of linen fabric stretched on a glass plate was $18 \%$ at the control, in version 3 it was maximum, i.e. three times the control $(54 \%)$ and in variants 2 and 4, i.e. with a moderate and very high dose of fertilizer was close and was respectively 40 and $35 \%$.

At the same time, the maximum nitrifying, ammonifying and cellulose-decomposing ability of the soil occurs in option 3, and it correlates with the content of mineral nitrogen and crop yield of the crop rotation.

In variants with moderate doses and very high doses of fertilizers, the decomposition of fiber is less pronounced, although it is higher than in the control. By the gradation of D.G. Zvyagintsev (1987), the soil under control has a weak one, in variants 2 and 4 it has an average, and in the variant with a nitrogen dose of $120 \mathrm{~kg} / \mathrm{ha}$, strong biological activity.

From this it follows that the optimization of the nitrogen state of the soil when applying nitrogen fertilizers in doses of 60 and $120 \mathrm{~kg} / \mathrm{ha}$ increases the biological activity of the soil according to this indicator.
With long-term use of very high doses of mineral fertilizers (option 4), the biological activity is somewhat reduced $[11,12]$.

Ammonification is the second stage of the nitrogen cycle in the soil and is carried out by ammonifying microorganisms. Ammonification is predominantly of the protein nitrogen of microorganisms, as well as of plants and animals [13].

In general, it is necessary to note the negative impact of the introduction of nitrogen fertilizers on the number of ammonifying microorganisms. However, this indicator does not always correlate with their activity (see table 2).

Table 2. The effect of fertilizers on the ammonifying capacity of the soil

\begin{tabular}{|c|c|c|c|}
\hline Option & $\begin{array}{c}\text { Total number of } \\
\text { microorganisms } \\
\text { million/g }\end{array}$ & $\begin{array}{c}\text { Ammonifying } \\
\text { microorganisms, } \\
\text { thousand/g }\end{array}$ & $\begin{array}{c}\text { Ammonifying } \\
\text { capacity, } \\
\text { mg/kg N-NH3 }\end{array}$ \\
\hline 1 & 3.4 & 2005 & 8.9 \\
\hline 2 & 3.9 & 1974 & 19.0 \\
\hline 3 & 4.0 & 1654 & 30.2 \\
\hline 4 & 3.3 & 1614 & 7.4 \\
\hline
\end{tabular}

* Note. 1. Control-without fertilizers. 2. $\mathrm{N}_{60} \mathrm{P}_{60} \mathrm{~K}_{40}$

3. $\mathrm{N}_{120} \mathrm{P}_{60} \mathrm{~K}_{120}$. 4. $\mathrm{N}_{180} \mathrm{P}_{60} \mathrm{~K}_{200}$

Another important indicator of the biological activity of the soil with long-term fertilizer is its toxicity and is associated with the intensive development of fungi. Fungi are one of the causes of toxin formation in the soil.

The determination of the total toxicity of the soil by biotesting showed that prolonged annual use of high doses of fertilizers somewhat increases the toxicity of the soil. However, it remains of low toxicity and belongs to hazard class 4 , and the soils of the control variant and with a moderate dose of fertilizers are not toxic and therefore there is no hazard class (see table 3).

Table 3. Effect of long-term application of fertilizers on soil toxicity

\begin{tabular}{|c|c|c|c|}
\hline Option & $\begin{array}{c}\text { Hazard } \\
\text { class }\end{array}$ & Characteristic & $\begin{array}{c}\text { Effect of inhibition of } \\
\text { roots, } \%\end{array}$ \\
\hline 1 & absent & Non-toxic & 0 \\
\hline 2 & absent & Non-toxic & 0 \\
\hline 3 & 4 & Low-toxic & 12 \\
\hline 4 & 4 & Low-toxic & 18 \\
\hline
\end{tabular}

*Note. 1. Control-without fertilizers. 2. $\mathrm{N}_{60} \mathrm{P}_{60} \mathrm{~K}_{40}$

3. $\mathrm{N}_{120} \mathrm{P}_{60} \mathrm{~K}_{120}$ 4. $\mathrm{N}_{180} \mathrm{P}_{60} \mathrm{~K}_{200}$

The productivity of crop rotation is measured by the total crop yield of crop rotation, it can be expressed in $\mathrm{kg} / \mathrm{ha}$ or $\mathrm{t} / \mathrm{ha}$ of grain yield. Prolonged use of mineral fertilizers in crop rotation in environmentally balanced doses contributed to an increase in its productivity by almost 2-fold compared with the control, which amounted to $250 \mathrm{~kg} / \mathrm{ha}$ feed units for 4 rotations at the control and $666 \mathrm{~kg} / \mathrm{ha}$ of fodder units. in the version $\mathrm{N}_{120} \mathrm{P}_{60} \mathrm{~K}_{120}$

All crops under crop rotation provided the highest yield in this variant. A further increase in fertilizer doses is not agronomically justified, since it adversely affects the soil biology and does not provide a further increase in yield. 


\section{Conclusion}

Based on the research we can draw the following conclusions:

1. Prolonged use of mineral fertilizers in environmentally balanced doses increases the biological activity of the soil and ensures high productivity of crop rotation.

2. Long-term use in the rotation of very high doses of mineral fertilizers adversely affects the microbiological state of the soil, while reducing the number of ammonifiers and nitrifying bacteria, actinomycetes, increasing the number of fungi and denitrifying bacteria, increasing the toxicity of the soil.

3. The use of very high doses of fertilizers in the crop rotation is ecologically and agronomically impractical, since it contributes to a decrease in the biological activity of the soil and does not ensure its maximum productivity.

4. Indicators of the biological activity of the soil correlate among themselves, as well as with other indicators of its fertility, with the productivity of crop rotation and therefore can serve as an additional diagnostic sign when assessing the anthropogenic stability of the agricultural soil of the agricultural soil in intensive agriculture.

\section{References}

1. S.Sh. Nuriev, A.A. Lukmanov, K.M. Khusnutdinov, I.N. Salimzyanova, Soil fertility status of the Republic of Tatarstan and problems of increasing their fertility (Kazan, 2009)

2. I.D. Davlyatshin, M.Yu. Gilyazov et al., Handbook of agrochemists (MedDoc Ltd., Kazan, 2013)

3. A. V. Koloskov, S. M. Gilyazova, A. Kh. Sakaeva, The humus state of the soils of the Volga-Kama forest-steppe (Publishing House of Kazan Univer., Kazan, 1985)

4. N.E. Zavyalova, A.I. Kosolapova, V.R. Yamaltdinova, The effect of long-term use of organic and mineral fertilizers on the transformation of organic matter in sod-podzolic soil, Agrochem., 6, 5-10 (2005)

5. N.E. Zavyalova, A.I. Kosolapova, V.R. Yamaltdinova, Biological indicators of fertility of sod-podzolic soil with long-term use of fertilizers, in Proc. of All-Russ. Sci. Method. Conf. "Geographical network of experiments with fertilizers," 116-121 (Moscow, 2006)

6. V.N. Bragin, Kh.S. Yumashev, Study of the influence of systematic use of fertilizers on crop yield, arable land productivity and soil fertility, Results of long-term studies in the system of a geographical network of experiments with fertilizers of the Russian Federation, 251-263 (VNIIA, Moscow, 2011)

7. L.G. Gaffarova, S.G. Murtazina, M.G. Murtazin, Dynamics of the humus state of gray forest soils of the Predkamye of the Republic of Tatarstan and the productivity of crop rotation with long-term fertilizer, Grain econ. of Russ., 2(50), 57-60 (2017)

8. S.G. Murtazina, L.G. Gaffarova, M.G. Murtazin, Assesment of environmental stability, IOP Conf. Ser. Earth and Environm. Sci. 3, Ecolog. Challenges of the 21st Century, ser. "21st Century 3rd Int. Conf. Environment \& Sustainable Development of Territories", 012120 (2018)

9. O.A. Berestetsky, T.N. Zubets, The influence of agricultural crops on the number of microflora and the biological activity of sod-podzolic soil, Soil Sci., 1, 94-99 (1981)

10. B. Yagodin, The Ring of Life. The Ring of Life Enthusiasts of agrarian science, Proceedings of Kuban State Agrarian University, 11, 28-202 (Krasnodar, 2010)

11. Soil and microorganisms (Moscow University Press, Moscow, 1987)

12. D.G. Zvyagintsev, Methods of soil microbiology and biochemistry, Soil and microorganisms (Moscow University Press, Moscow, 1987)

13. V.N. Kudeyarov, The nitrogen cycle in the soil and the effectiveness of fertilizers (Nauka, Moscow, 1989) 